\title{
Directive Illocutionary Act of Male and Female English Teachers in Junior High School
}

\author{
Euis Amalia ${ }^{1 * *}$ Rahmad Husein Napitupulu ${ }^{2 * *}$ Anni Holila Pulungan ${ }^{3}$ \\ ${ }^{1}$ English Applied Linguistics, Universitas Negeri Medan, Medan, Indonesia \\ ${ }^{2}$ English Applied Linguistics, Universitas Negeri Medan, Medan, Indonesia \\ ${ }^{3}$ English Applied Linguistics, Universitas Negeri Medan, Medan, Indonesia \\ *Corresponding Author. Email:euisamaliaa@gmail.com
}

\begin{abstract}
This research deals with directive illocutionary act which focused on the speech act showed between male and female English teachers where the teachers communicate with different gender has different way to communicate with the students where the students also divided into boys and girls. Some of teachers teach with different gender of the students. the process of teaching-learning is not as usual that an interaction between teacher and students face to face in the classroom, but the process is online. So this is different phenomenon happens from the previous research where the teaching- learning process is by online. The purpose of this research is to find out the types of directive illocutionary act performed by English teachers in Junior high school in different classes for academic 2020/2021. This research was conducted by using a descriptive qualitative method. In this research, the researcher found eight types of directive illocutionary act performed by English teachers. There were 39 sentences of command, 15request, 5 forbidding, 6 suggesting, 3 questioning, 6 permitting, 6 encouraging, and 8 wishing. In this research, the researcher found 4 reasons of directive illocutionary act performed by English teachers.
\end{abstract}

Keywords: Speech Act, Directive illocutionary Act, Teaching Process.

\section{INTRODUCTION}

Language is an essential thing used to communicate with each other in daily life. It depends on human used to communicate with each other. The language produced by utterance which it is not only to share or explain the mind but also to show the utterance between the speaker and mind and its utterance. So the utterance can be seen from Speech Act in the real situation which happens between speaker and listener, whether the utterances sometimes are not direct, but it is only by screen.

The act is used to achieve some communicative process, such as asking, ordering, suggesting, requesting, informing, advising, and greeting which the process is described as illocutionary act. As Searle (1969) states that there are four categories of illocutionary act, such as representative, directive, commissive, and expressive. Some acts are used for education especially for learning activity in the class, especially for English subject. English is very important for the students to develop their English skill. English needed for many lessons, like speaking or writing. Teachers as the main role in teaching the language have many ways to make English is easy to understand and fun. The teaching way is based on the students' condition. It means that teaching English to junior high school students will be different from other level class, actually it can be seen from the age, social role to find appropriate ways to make students enjoy and happy to learn English.

The teacher has an important role in the class for the students, because the teacher will transfer the lesson, so the students are the target language where the teacher's utterance can be as a motivation, instruction, direction, explanation which most of them are defined as speech act. Charlina (2018) proves that speech and strategy were used by the teachers in special school learning proses. The research investigates in a special school in Pekanbaru. The research method uses an observation.

Based on the illustration of illocutionary act, the researcher finds out an important expectation in this study to analyze the one of types of directive illocutionary act which occurs in teaching-learning process where the illocutionary act most often used in a song or movie, but in this researcher, the researcher has an expectation that this illocutionary act happens in a teaching-learning process as the previous study shows that there are many researches have conducted in a song or movie, or in the classroom but it only focused on the students' EFL while in this researcher, the researcher gets a new phenomenon will be investigated in this classroom.

In this study, the researcher interested to analyze speech act, especially on directive illocutionary act 
because the English teacher performs his or her teaching is directive to the students where in this study the researcher will analyze the teacher from Female who teach Male students and from Male who teach female students in the classroom, so it relates to directive illocutionary act and the function of directive illocutionary act is to affect student form teacher's utterances where it has a different way from the utterance of male and female teachers during teaching- learning process in different gender of each class. In this process, the process of teaching-learning is not as usual that an interaction between teacher and students face to face in the classroom, but the process is online.

\section{LITERATURE REVIEW}

Speech act is an utterance when someone utters something to the people, but it is not always describing an utterance even it can be something that the people do from the utterance, so speech act is an utterance to perform an action. The speech act is used to describe an action, such as question, command, request.

Austin (1969) states that the utterance is used to describe or show something whether the result of communication is true or false, and the utterance is not only performs a speech act. Austin divided three parts of speech act, they are locutionary act, illocutionary act, and perlocutionary act. The locutionary act occurs when it is related on the phonetic, phonology, and linguistic semantic which it is used to ask the meaning of communication because it can get miscommunication between the speaker and the listener. While the illocutionary act is an action used by the speaker to say something, such as making promise, thanking, asking a question so in this part the illocutionary act performs in utterance to get the purpose of each communicative, and the perlocutionary act is an action that the speaker performs by saying something in a particular context of communication, but without intending it to the affect.

While Allan (1986) states that speech act is one of the way of the speaker to convey or send a message to the listener from hie or her utterance, such as making a question, request, command and so on. Then Baleghizadeh (2007) defines that speech act is used as a functional communication where it can carry a single meaning of communication in different point of view based on the context or situation.

From the definition above, it can be sated that the speech acts are utterance use which contain as an action that can consider whether the aspect of situation from the speaker and it can be interpreted as a result of speech act in its meaning and use a certain situation to get the result of communication is filled of the meaning. So in this research the researcher uses this theory of Baleghizadeh to apply this study because the theory used is related to three aspects, such as locutionary act, illocutionary act, and perlocutionary act where one of the aspects will be investigated in this research and this theory is relevant to this study based on the problems of this research. Where in this study, the researcher only focuses on the illocutionary act which occurs to male and female English teachers in teaching- learning process in online.

Searle (1969) states that directive is one of illocutionary act used to make someone or hearer do something from the speaker in the future, it is as a direction like command, request, ask and so on that refers to the direction to do something. In this case directive illocutionary act takes from the speaker's utterance. The utterance of the illocutionary act is different from other utterances because the function of directive illocutionary act itself, so the utterance is not equal each other, there are some difference of the utterance based on the function of directive illocutionary act. for example, when the speaker request something to the hearer so the hearer intends to do something from the speaker. As Cutting (2002) states that Directive illocutionary act contains eight types with each function from the speaker's utterance, so the utterance has different type based on each function itself.

Searle (1969) states that directives are used to produce some affects from the hearer. This is the highest frequency for the classification of illocutionary act because this happens in the classroom used by the speaker especially on English teacher that gives more instruction to the students to do something related to teaching- learning process. For example, like ordering, asking, commanding, requesting and other expressions used by the speaker on directive illocutionary act. It means that the act is used directly by male and female English teachers by classifying of types directive illocutionary act used by the theory used.

\section{RESEARCH METHOD}

This research uses a descriptive qualitative research. This research will be applied by the researcher to answer three questions and the researcher can describe the types of directive illocutionary act in teachinglearning process. The purpose of this method to get deep understanding about the phenomenon than numeric analysis. In this case before doing the study, the researcher should find the issue and the problem of that issue that will be analyzed. The researcher should have a specific reason to do that research.

The data of this study will be sentences consisting of directive illocutionary act of male and female English Teachers during teaching- learning process. As frank (1972) states that the classification of sentence is divided into three parts, namely declarative, interrogative, and imperative sentence. The sentences are chosen by considering the theory of directive illocutionary act of Cutting's theory. The source of the data will be taken from four English teachers especially on the sentences of the utterance itself during teaching-learning process that will be divided into male and female in one of Islamic schools in SMP Ad-Durrah Medan, because this school 
is one of Islamic schools in Medan where the students are separated between boys and girls in each class.

The instrument of this research will be the researcher herself. The supporting instrument will be an observation of teaching learning process of directive illocutionary act and interview with the teachers to collect some documents and take some photographs of the teaching-learning process as documentation of the research. Esterberg (2002) states interview as an information of the research to find the data from the teachers. In this case the researcher will observe the document first then interview the teachers. The researcher will record the information. The data of this research will be collected by applying observation by taking eight meeting for English teachers in the classroom where it will be used to find a type, function and reason of directive illocutionary act on teachinglearning process and interview the teachers why directive act occurs to English teachers during teaching-learning process, while Cresswell (2012).

Qualitative data analysis techniques according to Bogdan and Biklen (1989) is an effort done by working with data, organizing data, sorting data into manageable units, synthesizing, searching, and finding patterns, finding what is important and what is learned and decide what can be told to others. The next step is to process the data collected by analyzing the data, describing the data, and drawing conclusions.

\section{RESULT AND DISCUSSION}

The finding of this study was found through steps by steps. First, the data of this study were taken from the male and female English teachers who teaches at the junior school in different classes during teaching-learning process through online learning.

The process of teaching-learning process was affected by the way of their teaching in different way to different classes and different gender because this is a new phenomenon where the Mele teacher teaches Female students and female teachers teach male students. The process is different with the public school where the students are not separated between boys and girls, and in this school it was separated among boys and girls. From the process, the researcher could find the data of directive illocutionary act occurred in teaching-learning process through online learning by the English teachers.

Based on the types of directive illocutionary act by English teachers proposed by cutting 2002 were found in each teachers when they had a class to his / her students. The most type appeared in each sentences were command. The researcher analyzed the sentences of each English teachers were appeared that there were thirty one times for command in each teachers, three times requesting, six times for suggesting, five times for forbidding, twice for questioning, seven times for permitting, four times for encouraging, and eight times for wishing.
It can be seen from the data during teaching-learning process of Male and female English teachers when they gave an assignment or something to do by the students. In this process the teacher only shares assignments to the students by online- learning and the book. It can be seen from the process of teaching learning that the students only get more assignments from the teachers. So there are some problem during the process teaching-learning, as an example from the male teacher instructs the students, such as:

\section{M.T: - open your book page 43}

- choose one of the words in the brackets

To complete the sentences

- Prounounce the following noun phrase correctly!

M.T: - Lets's pray before we learn the subject

- Look at the characteristic of procedure text!

- Such as: using simple pesent tense, cpmmand, using number, using conjunction.

F.T: $\quad$ - Find the respond for the following messages. Draw lines between them

- Work in pairs. Complete the dialog then practice it

- Work in pairs. Complete the dialog then practice it

F.T : - Write the following times in words

- Choose either cardinal number or ordinal numbers to complete the following sentences

- Write down the dates. number one has done for you as an example.

Based on the data above of the examples from male and female teachers show that male and female English teachers have different way to communicate with the students where in this case males teach for female students and females teach for male students. So in this case, this research is a new phenomenon happen which haven't conducted yet from the previous research

In this study, the researcher made an organization by showing the data and it can be seen in this table which the most appeared of each sentences. The researcher displayed the data into the following table. 
Table 4.1. Types of Directive Illocutionary Act of Male and Female English teachers

\begin{tabular}{|r|l|r|r|}
\hline No & $\begin{array}{l}\text { Types of } \\
\text { Directive } \\
\text { Illocutionary } \\
\text { Act }\end{array}$ & Number & Percentages \\
\hline 1 & Command & 39 & 43.33 \\
\hline 2 & Request & 15 & 16.66 \\
\hline 3 & Suggest & 6 & 6.66 \\
\hline 4 & Forbid & 5 & 5.55 \\
\hline 5 & Question & 3 & 3.33 \\
\hline 6 & Permit & 3 & 3.33 \\
\hline 7 & Encourage & 9 & 10 \\
\hline 8 & Wish & 4 & 4.44 \\
\hline 9 & Statement & 90 & 100.00 \\
\hline & Total & & \\
\hline
\end{tabular}

Based on the table above, it could be seen that there were nine types of directive illocutionary act used by male and female English teachers which was found in the data analysis above. It means that the most percentages in this types was command, because in this research occurred in teaching- leaning process of male and female English teachers to each student. During the process of teachinglearning process, the researcher analyzed the data based on the problem and it could be seen that most of the teachers used a command to the student, where command was used to instruct someone directly, means that in this teaching-learning process, the teachers instructed the students to do something for their teacher related to the lesson. In this type there were some categories included, namely: beg, charge, demand, dictate, instruct, order, prescribe, require.

\section{CONCLUSION}

All the types of directive illocutionary act used by male and female English teachers, where this study was concern on the types of directive illocutionary act, namely; command, request, suggest, forbid, question, permit, encourage, wish, and statement, The mostly types of directive illocutionary act used by male and female English teachers was command because this study occurred during teaching-learning process and the mostly function related to the types of directive illocutionary act used was instruction as the data was seen that the English teachers conducted this study during teaching- learning process, There were some reasons using directive illocutionary act used by male and female English teachers. The most dominant frequently used was content condition where the speaker warns the hearer to do something and it relates to the types of directive illocutionary act used by male and female English teachers.

\section{REFERENCES}

[1] Adams, N. P. (2019). Authority, Illocutionary, and. Australasian Journal of Philosophy, 3-15.

[2] Anita Sitanggang, H. S. (2020). Illocutionary Act in Song lyrics of Taylor Swift's Single 'Love Story'. Global Scientific Journal, 8.

[3] Ary, D. (2010). Introduction to Research Education. USA.

[4] Chairani, M. (2020). Illocutionary and Perlocutionary Acts on YouTube Videos Employed by Niana Guerrero. Journal of English Education and Teaching (JEET), 4.

[5] Charles.F. (2009). Introducing English Linguistic. NewYork:Cambridge University Press.

[6] Creswell, J. W. (2012). Educational Research :planning, conducting, and evaluating qualitative and quantitative research. Boston.

[7] Frank, M. (1972). A Practical Reference Guide. NewJersey: PrenticeHall. 